\title{
Assessment of Some Haemostatic Parameters Among Diabetes Mellitus Patients in Bayelsa State: A Case Study at the Federal Medical Centre, Yenagoa
}

\author{
Benjamin Onyema Eledo ${ }^{1,2}$, Michael Ifesinachi Nwoga ${ }^{1}$, Okezie Caleb Okamgba ${ }^{3}$, \\ Sylvester Chibueze Izah ${ }^{4, *}$ \\ ${ }^{1}$ Department of Medical Laboratory Science, Faculty of Health Sciences, Madonna University, Nigeria, Elele \\ ${ }^{2}$ Haematology and Blood Transfusion Department Federal Medical Centre, Yenagoa, Nigeria \\ ${ }^{3}$ Department of Medical Laboratory Science, Abia State University, Uturu, Nigeria \\ ${ }^{4}$ Department of Biological Sciences, Faculty of Science, Niger Delta University, Wilberforce Island, Nigeria
}

\author{
Email address: \\ chivestizah@gmail.com (S. C. Izah) \\ ${ }^{*}$ Corresponding author
}

\section{To cite this article:}

Benjamin Onyema Eledo, Michael IfesinachiNwoga, Okezie Caleb Okamgba, Sylvester ChibuezeIzah. Assessment of Some Haemostatic Parameters Among Diabetes Mellitus Patients in Bayelsa State: A Case Study at the Federal Medical Centre, Yenagoa. European Journal of Clinical and Biomedical Sciences. Vol. 3, No. 5, 2017, pp. 91-96. doi: 10.11648/j.ejcbs.20170305.12

Received: August 13, 2017; Accepted: September 5, 2017; Published: October 6, 2017

\begin{abstract}
Diabetes mellitus is a chronic metabolic disorder characterized by elevated blood glucose levels. This study investigated some haemostatic parameters among diabetes mellitus patients attending diabetes clinic at the Federal Medical Centre Yenagoa; A tertiary health institution. One hundred and eleven individuals participated in this study, comprising 31 females and 25 males (diabetes mellitus patients) and 30 females and 25 males (control subjects). Blood was collected from the participants and the prothrombin time, activated partial thromboplastin time and platelets count were analyzed using standard procedures. Results showed mean values in females and males as $10.84 \pm 2.18$ and $11.28 \pm 0.86$ seconds respectively (prothrombin time), $29.26 \pm 2.16$ and $30.93 \pm 2.43$ seconds (activated partial thromboplastin time), $401.94 \pm 59.20$ and $402.20 \pm 41.72 \times 10^{9} / \mathrm{L}$ respectively (platelets counts) for the diabetes mellitus patients and $12.74 \pm 1.42$ and $12.34 \pm 1.09$ seconds respectively (prothrombin time), $32.81 \pm 1.76$ and $32.77 \pm 1.46$ seconds (activated partial thromboplastin time), $263.33 \pm 55.32$ and $282 \pm 51.03$ $\mathrm{x} 10^{9} / \mathrm{L}$ respectively (platelets counts) for the control groups. There was significant variation $(\mathrm{P}<0.002)$ among both group of subjects for each of the sex. Prothrombin time and activated partial thromboplastin time were significantly lower while platelets counts were significantly higher in the diabetes mellitus patients compared to the control. Lower prothrombin time and activated partial thromboplastin time suggest hyper-coagulability which may lead to adverse cardiovascular and thrombotic complications among the diabetes mellitus patients. While an elevated platelets counts is an indication of increased platelets function which could lead to vascular complications.
\end{abstract}

Keywords: Diabetics, Haemostatic Parameters, Prothrombin Time, Activated Partial Thromboplastin Time, Platelets Counts

\section{Introduction}

Diabetes mellitus is a chronic metabolic disorder characterized by elevated blood glucose levels [1 - 5]. According to Ezuruike and Prieto[6], Ndiok et al. [1], AlJameil et al. [7], high blood glucose concentration may be associated to insufficient endogenous insulin production by the pancreatic beta cells for type-1 diabetes or dyfunctioning of insulin secretion for type 2 diabetes. Diabetics are associated with several disease burdens in developing nations like Nigeria [8]. As such, diabetes is one of the major source of morbidity and mortality. Ezuruike and Prieto[6], Ndiok et al. [1], Al-Jameil et al. [7] reported that the risk factors of diabetes are in the increasing trend. Diabetes could lead to several health problems such as kidney failure, heart disease, stroke and blindness [9].

Globally, the prevalence of diabetes has been reported in literatures. Globally, diabetes has affected over 370 million 
people leading to about 5 five million deaths and over 471 USD is used annually during treatment [10]. Roglic and Unwin[11] reported that diabetes leads to about 3.96 million death among the age group of 20-79 years. Diabetes incidence rate appears to vary according to region. For instance, Roglic and Unwin [11] reported death rate of $6 \%$ and $15.7 \%$ in Africa and North America. Fadairo et al. [12] also reported the prevalence rate of diabetes in Africa to be $4.3 \%$ and about 15 million people are living with the disease. According to Diabetes Leadership forum [13], Ndiok et al. [1], about 12 million persons had diabetes in sub-sahara Africa in 2010 leading to over 330,000 deaths and other complications. The authors also reported that incidence projection may reach 23.9 million by 2030 . WHO suggests that Nigeria has the highest number of people living with diabetes in Africa, with a probable load of about 1.7 million which is estimated to rise to 4.8 million by 2030 [2]. According to International Diabetes Federation, incidence of diabetes was 19million in 1995 which reached 40.9 million in 2007 [5]. Based on sex and age, diabetes tends to affect females above 49 years compared to men of same age grade [11].

Two major types of diabetes exist including Type 2 diabetes also known as non-insulin depended diabetes mellitus $[3,9,14]$. This type of diabetes could lead to the production of insulin resistance and sub normal functioning of the beta cell $[1,6,15,16]$. Type 2 diabetes incidence increases with age especially from 35 years of age [9]. Kakouros et al. [15] reported that Type 2 diabetes accounts for $90-95 \%$ of all diabetic cases.

On the other hand, type 1 diabetes also exists and it causes autoimmune disease characterized by $\mathrm{T}$-cell mediated destruction of the pancreatic beta cells with the resultant effect of absolute insulin deficiency $[1,6,7,16]$. Type 1 diabetes mostly occurs in children and adolescents while the type 2 majorly occurs in the elderly. According to Uko et al. [16], about $5-10 \%$ of total global diabetes cases is associated to type 1 .

Blood plays essential role in humans as well as animals. According to Etim et al. [17], blood acts as a pathological reflector in animals exposed to some certain conditions. The authors also reported that assessment of blood provides essential status about the physiological, nutritional and pathological condition of such organisms. Variation in blood could depend on age, sex, genetics, health status etc. Several haematological parameters are used in assessing health status of a patient. The parameters are dependent on the organ and/ or parameter of interest. For instance, in determining malaria parasite in human, malaria count is assessed, blood glucose test is often carried out to assess sugar level in the body, and parameters such as alkaline phosphatase, albumin, total protein, total bilirubin, conjugated bilirubin, alanine transaminase, aspartate transaminase are carried out to assess liver functions [1]. Some other parameters that blood is used for analysis include globulin, albumin/globulin,cholesterol, triglyceride, urea nitrogen, creatinine, chloride, potassium, calcium, sodium, bicarbonate, phosphate, random blood sugar, red blood cells count, neutrophils, lymphocyte, monocyte, eosinophil, basophil counts, haemoglobin, haematocrit, mean corpusular volume, mean corpuscular haemoglobin, mean corpuscular haemoglobin concentration etc.

Impairment in certain haematological parameters due to pathological defects may affect other blood parameters. For instance, Uko et al. [16] reported that Type1 Diabetes affects platelets count, total white blood cell and packed cell volume. Zhao et al. [18] reported that activated partial thromboplastin time is one of the haemostatic markers in diabetic patients. Therefore, this present study aimed at assessing the effects of diabetes mellitus (if any) on some haemostatic parameters such as Prothrombin time, Activated partial thromboplastin time and Platelets counts among patients attending the diabetics clinic at the Federal Medical Centre in Yenagoa metropolis, Bayelsa state.

\section{Materials and Methods}

\subsection{Study Area}

Yenagoa is the capital of Bayelsa state in the Niger Delta region of Nigeria. Bayelsa state is located within Latitude $4^{0}$ $15^{\prime}$ North and Latitude $5^{\circ} 23^{\prime}$ South and longitude $5^{\circ} 22^{\prime}$ West and $6^{0} 45^{\prime}$ East [19]. Bayelsa state share boundary with Delta State in the North, Rivers State in the East and the Atlantic Ocean in the Southernmost parts [19]. Fishing is a major occupation of indigenous people of the area. Majority of the inhabitants of Yenagoa metropolis are Civil servants and few are businessmen and women. The climatic condition has been severally reported in literatures [20 - 33].

\subsection{Selection Criteria for Subjects}

Inclusion Criteria: Subjects for this research were individuals attending the diabetes clinic of the Federal Medical Centre Yenagoa. Only those who have suffered diabetes mellitus for more than five years were recruited for the study. A Total of fifty six (56) diabetes patients participated in this study which comprised of males (25) and females (31) within the age of $52-75$ years. Also control subjects were confirmed to be non-diabetics using Medi-Test Combi 9 qualitative and semi-quantitative urinalysis test strips. Kit supplied by Macherey-Nagel Germany; Lot number: 32651. A total of fifty five (55) control subjects made up of 25 males and 30 females within the age of 18 30 were recruited for the study.

Exclusion criteria: Pregnant women and individuals with known cases of hepatitis, tuberculosis were excluded. Also, subjects with history of cardiovascular diseases, bleeding or clotting disorders were excluded from the study.

\subsection{Blood Collection}

A standard venipuncture technique was used to collect $5 \mathrm{ml}$ of blood from each subject from the anticubital or dorsal vein. Approximately $2.25 \mathrm{mls}$ was dispensed into a plastic tube containing $0.25 \mathrm{ml}$ of trisodium citrate. This was used 
for prothrombin time and activated partial thromboplasting time using kits supplied by Agappe Diagnostics Switzerland. The remaining blood sample was dispensed into dipotassium EDTA bottles containing $1.5 \mathrm{mg} / \mathrm{ml}$ of blood of the anhydrous salt. This was used for platelets count using the Cronkit's ammonium oxalate method.

\subsection{Laboratory Analysis}

\subsubsection{Prothrombin Time}

Principle: Tissue thromboplastin in the presence of $\mathrm{Ca}^{++}$ activates extrinsic pathway of human blood coagulation cascade. Activation time is proportional to the concentration of individual clotting factors taking part in the coagulation cascade. When thromboplastin reagent is added to citrated plasma, clotting cascade is initiated forming gel clot. The time required for clot formation would be prolonged if there is deficiency of factor(s) activity in the extrinsic pathway of the coagulation cycle.

Procedure:

The PT REAGENT was pre-warmed to $37^{\circ} \mathrm{C}$ for 10 minutes.

$0.1 \mathrm{ml}$ of plasma was dispensed into test cuvette at $37^{\circ} \mathrm{C}$ and incubated for 3 minutes.

$0.2 \mathrm{ml}$ of pre-warmed PT REAGENT was forcibly added into the test cuvette.

The timer was started simultaneously and the time for the first clot to appear was recorded in seconds.

The test was done in triplicate and the average time was recorded as the prothrombin time

The control samples were treated same.

Kit supplied by Agappe Diagnostics Switzerland. Lot number: 52601003

\subsubsection{Activated Partial Thromboplastin Time}

Principle: In the presence of calcium ions cephaloplastin activates coagulation factors of intrinsic pathway in plasma leading to clot formation. Clotting time is proportional to the concentration of factors viii, ix, $x i$ and xiii as well as common pathway factors $\mathrm{ii}, \mathrm{v}$, and $\mathrm{x}$.

Procedure:

Reagent $1\left(\mathrm{Cacl}_{2}\right)$ and reagent 2 (APTT REAGENT) were pre-warmed at $37^{\circ} \mathrm{C}$

$0.1 \mathrm{ml}$ of test/control plasma was dispensed into test cuvette at $37^{\circ} \mathrm{C}$

$0.1 \mathrm{ml}$ of the pre-warmed reagent was added into the test cuvette, mixed and incubated at $37^{0 \mathrm{c}}$ for 3 minutes.

$0.1 \mathrm{ml}$ of pre-warmed reagent 1 was forcibly added into the test cuvette.

The timer was started simultaneously and the time for the first clot to appear was recorded in seconds.

The test was done in triplicate and the average time was recorded as the activated partial thromboplastin time.

Kit supplied by Agappe Diagnostics Switzerland. Lot number: 52602001

\subsubsection{Platelets Count}

This was based on the Cronkite's ammonium oxalate method where the red cells were lysed and the platelets left as highly refractile particles under illumination. A 1:20 dilution of blood was made by adding $0.1 \mathrm{ml}$ of blood to $1.9 \mathrm{ml}$ of diluents (ammonium oxalate). The suspension was well mixed and an improved Neubauer counting chamber covered with cover slip was charged with the suspension and left untouched in the moist petri-dish for about 20 minutes to allow the platelets to settle. The number of platelets in two areas of $1 \mathrm{~mm}$ square were counted using x40 objective. The number of platelets per litre was calculated from the formula:

$$
\text { Platelets }=\frac{\text { Number of cells counted } \mathrm{x} \text { dilution } \times 10^{6}}{\text { volume }(\mu \mathrm{l})}
$$

\subsection{Statistical Analysis}

Statistical analysis was carried out using SPSS software version 20. Data were presented as mean \pm standard deviation and range i.e. minimum to maximum is presented in parenthesis. The haemostatic values obtained for diabetic and non-diabetic patients were subjected to " $\mathrm{t}$ " test. Significance level was determined at P-value $<0.05$.

\section{Results and Discussion}

Table 1 and 2 present the effects of diabetes mellitus on some haemostatic parameters in females and males attending diabetics clinic in Federal Medical Centre, Yenagoa, Bayelsa state, Nigeria. In the female, the prothrombin time was 10.10 -13.20 and $10.70-15.10$ seconds in subjects and controls respectively (Table 1 ). In the male, prothrombin time was $10.30-13.50$ and $10.44-14.40$ seconds in subjects and controls respectively (Table 2 ). In both sexes, prothrombin time was significantly $(\mathrm{P}<0.001)$ lower in diabetic patients compared to the control group. The trend could be due to the facts that diabetes patients have hypercoagulable tendency resulting from a shift of thrombo-haemorrhagic balance in favor of thrombosis [34]. The results of this study is contrary to the work of Elhassade and Balha[3] who reported no significant variation between diabetic patients and control subjects with regard to the prothrombin time; Abdulrahaman and Dallatu[35], Alao et al. [34] who reported a significant higher prothrombin time among diabetic patients compared to the control group. But in agreement with the work of Karim et al. [36] who reported significant lower prothrombin time in diabetic patients compared to control group.

Typically, prothrombin time, activated partial thromboplastin time are blood coagulation parameters [37]. Karim et al. [36] further asserted that diabetic conditions lead to hypercoagulable conditions among diabetic patients which enhances thromboembolic risk for cardiovascular disease. Kakouros et al. [15] reported that diabetes mellitus patients have an enhanced prevalence of vascular disease such as thrombosis due to atherosclerotic plaque rupture.

In females, the activated partial thromboplastin time were in the range of $25.30-33.70$ seconds and $29.80-36.50$ seconds for subjects and control group respectively, being 
statistically $(\mathrm{P}<0.001)$ lower in the diabetic patients compared to the control groups (Table 1). Like in females, the activated partial thromboplastin time in males was in the range of $26.50-36.30$ seconds and $30.10-35.70$ seconds in the diabetic subjects and controls respectively. There was significant variation $(\mathrm{P}<0.002)$ between the diabetic patients and the control group (Table 2). Activated partial thromboplastin time was statistically lower in diabetic patients compared to the control (Table 1 and 2). Typically, activated partial thromboplastin time is a coagulant parameter used in assessing abnormalities in the contact (factor XII, prekallikrein, and high-molecular-weight kininogen), intrinsic (factors XI, VIII, IX) and common (factors $\mathrm{X}, \mathrm{V}$ and II and fibrinogen) mechanisms of coagulation [3]. According to Elhassade and Balha [3], Alao et al. [34], lower activated partial thromboplastin time often indicate hyper-coagulable conditions leading to increased risk of adverse cardiovascular and thrombotic events. The findings of this study is comparable to the work of Elhassade and Balha [3], Zhao et al. [18], Sapkota et al. [38] that reported significant lower activated partial thromboplastin time in diabetic patients. But contrary to the work of Abdulrahaman and Dallatu [35], Alao et al. [34] that reported a significant higher prothrombin time among diabetic patient compared to the control group.

Table 1. Effect of diabetes on some haemostaticparameters in females.

\begin{tabular}{|c|c|c|c|c|}
\hline \multirow{2}{*}{ Parameters } & \multicolumn{2}{|l|}{ Mean \pm standard deviation } & \multirow{2}{*}{ t-value } & \multirow{2}{*}{ P-value } \\
\hline & Subjects $(n=31)$ & Control $(n=30)$ & & \\
\hline Prothrombin time (PT), seconds & $10.84 \pm 2.18(10.10-13.20)$ & $12.74 \pm 1.42(10.70-15.10)$ & -4.014 & 0.000 \\
\hline $\begin{array}{l}\text { Activated partialthromboplastin time (APTT), } \\
\text { seconds }\end{array}$ & $29.26 \pm 2.16(25.30-33.70)$ & $32.81 \pm 1.76(29.80-36.50)$ & -7.024 & 0.000 \\
\hline Platelets counts $(\mathrm{PLT})\left(\mathrm{x} 10^{9} / \mathrm{L}\right)$ & $401.94 \pm 59.20(257.00-503.00)$ & $263.33 \pm 55.32(156.00-370.00)$ & 9.441 & 0.000 \\
\hline
\end{tabular}

Table 2. Effect of diabetes on some haemostatic parameters in males.

\begin{tabular}{|c|c|c|c|c|}
\hline \multirow{2}{*}{ Parameters } & \multicolumn{2}{|l|}{ Mean \pm standard deviation } & \multirow{2}{*}{ t-value } & \multirow{2}{*}{ P-value } \\
\hline & Subjects $(n=25)$ & Control $(n=25)$ & & \\
\hline Prothrombin time (PT), seconds & $11.28 \pm 0.86(10.30-13.50)$ & $12.34 \pm 1.09(10.44-14.40)$ & -3.867 & 0.000 \\
\hline Activated partialthromboplastin time (APTT), seconds & $30.93 \pm 2.43(26.50-36.30)$ & $32.77 \pm 1.46(30.10-35.70)$ & -3.299 & 0.002 \\
\hline Platelets counts (PLT) & $402.20 \pm 41.72(317.00-516.00)$ & $282.42 \pm 51.03(194.00-417.00)$ & 9.156 & 0.000 \\
\hline
\end{tabular}

The Platelets counts for the subjects and control group were $257.00-503.00 \times 10^{9} / \mathrm{L}$ and $156.00-370.00 \times 10^{9} / \mathrm{L}$ respectively in females, being significantly different $(\mathrm{P}<0.001)$ among the test subjects (Table 1). While the concentration ranged from $317.00-516.00 \times 10^{9} / \mathrm{L}$ and $194.00-417.00 \times 10^{9} / \mathrm{L}$ in test subjects and control respectively for males, being significantly different $(\mathrm{P}<0.001)$ among the test subjects (Table 2). The platelet count in this study was significantly higher in the diabetic patients compared to the control group. This could be due to stress response resulting from the metabolic disorder/ syndrome [16]. An increased platelets count is usually observed in patient with prolonged diabetic cases. As such, elevated platelet levels could lead to platelet dysfunction and have adverse effect to the microcirculation and boost the risk of vascular complications [16]. Typically, platelets play an essential role in the initiation and propagation of thrombosis 15] such as collagen, thrombin [39]. The findings of platelets in this study is comparable to the work of Uko et al. [16], that reported significant increase in diabetics patients (464.72 $\left.\mathrm{x} 10^{9} / \mathrm{L}\right)$ compared to the control group $\left(297.13 \times 10^{9} / \mathrm{L}\right)$.

Based on comparison with other human habit such as smoking, the findings of this study is contrary to the observation made on marijuana smokers where Eledo et al. [19] reported Prothrombin time of 13.17 seconds and 12.61 seconds in control and subjects respectively, activated partial thromboplastin time of 33.63 seconds and 33.64 secondsin control and subjects respectively and platelets counts of 194 $\mathrm{x} 10^{9} / \mathrm{L}$ and $224.00 \times 10^{9} / \mathrm{L}$ in control and subjects respectively. The authors also reported no significant difference $(\mathrm{P}>0.05)$ among the test subjects. Furthermore, Asif et al. [40] reported platelets count of $252.25\left(10^{3} / \mu 1\right)$ and $270.28\left(10^{3} / \mu \mathrm{l}\right)$ in smokers and non-smokers respectively in male population of Quetta city in Pakistan. The authors further reported that no significant different exists among both subject.

\section{Conclusion}

This study assessed some haemostatic parameters such as prothrombin time, activated partial thromboplastin time and platelets counts among diabetes mellitus patients attending diabetics clinic at the Federal Medical Centre in Yenagoa metropolis, Bayelsa state. The findings of this study showed that diabetic health conditions affect the prothrombin time, activated partial thromboplastin time and platelets counts of patients. The change in these parameters could predispose the diabetes mellitus patients to hypercoagulability which may lead to vascular complications. The trend of prothrombin time,activated partial thromboplastin time and platelets counts were similar in both sex (i.e. male and female).

\section{Ethical Consideration}

Permission was obtained from the ethics committees of the Medical Laboratory Science Department of Madonna University, Nigeria, Elele and Federal Medical Centre Yenagoa, Nigeria. Informed consent was obtained from the 
patients prior to sample collections.

\section{Acknowledgements}

This publication is based on the undergraduate project work of Nwoga Michael Ifesinachi and supervised by Dr. Eledo, B.O. at Madonna University Elele, Nigeria.

\section{References}

[1] Ndiok, E. O., Ohimain, E. I. and Izah, S. C. (2016). Incidence of Malaria in Type 2 Diabetic patients and the effect on the liver: a case study of Bayelsa state. Journal of Mosquito Research, 6(15): 1-8.

[2] Chinenye, S., Uloko, A. E., Ogbera, A. O., Ofoegbu, E. N., Fasanmade, O. A., Fasanmade, A. A. and Ogbu, O. O. (2012). Profile of Nigerians with diabetes mellitus-Diabcare Nigeria study group (2008): Results of a multicenter study. Indian J EndocrMetab, 16:558-564.

[3] Elhassade, A. S. and Balha, O. S. (2016). Effect of diabetes mellitus type II on activated partial thromboplastin time and prothrombin time. Int J Clin and Biomed Res., 2(3): 1-4.

[4] Nwafor, A. and Owhoji, A. (2001). Prevalence Of Diabetes Mellitus Among Nigerians In Port Harcourt Correlates With Socio-Economic Status. J. Appl. Sci. Environ. Mgt. 5(1): 7577.

[5] Sivasakthi, M. (2017). Efficacy of Supplementation of Cloves and Cinnamon Capsules on Type II Diabetics. Nutrition and Food Toxicology, 1(4): 130-139.

[6] Ezuruike, U. F., and Prieto, J. M. (2014). The use of plants in the traditional management of diabetes in Nigeria: Pharmacological and toxicological considerations. Journal of Ethnopharmacology, 155: 857-924.

[7] Al-Jameil, N., Khan, F. A., Arjumand, S., Khan, M. F. and Tabassum, H. (2014). Associated liver enzymes with hyperlipidemic profile in type 2 diabetics patients, International Journal of Clinical and Experimental Pathology, 7(7): 4345-4349.

[8] Ogbera, A. O. and Ekpebegh, C. (2014). Diabetes mellitus in Nigeria: The past, present and future. World J Diabetes, 5(6): 905-911.

[9] Adebisi, T. T. (2013). Assessment of Nutritional Status of Diabetic Patients in Ogun State, Nigeria. American Journal of Human Ecology, 2(4): 120-126.

[10] Boutayeb, W., Lamlili, M. E. N., Boutayeb, A. and Derouich, M. (2014). MathematicalModellingandSimulationof $\beta$ CellMass,Insulinand Glucose Dynamics: Effect of Genetic Predisposition to Diabetes. J. Biomedical Science and Engineering, 7: 330-342.

[11] Roglic, G. and Unwin, N. (2010). Mortality attributable to diabetes: Estimates for the year 2010. Diabetes Research and Clinical Practice, 87: 15-19.

[12] Fadairo, J. K., Atere, A. D., Ogidiolu, T. O. And Abiodun, O. P. (2016). Assessment of Some Coagulation Indices among Type II Diabetic Subjects in a Tertiary Facility in South West Region, Nigeria. IOSR Journal of Dental and Medical Sciences, 15(6): 159-163.
[13] Diabetics Leadership Forum (2010). Diabetes: the hidden pandemic and its impact on sub-Sahara Africa.

[14] Ikekpeazu, E. J., Neboh E. E., Maduka I. C., Nwagbara I. J., and Nwobodo M. W. (2010). Type-2 Diabetes Mellitus and Malaria Parasitaemia: Effect on Liver Function Tests. Asian Journal of Medical Sciences, 2(5): 214-217.

[15] Kakouros, N., Rade, J. J., Kourliouros, A. and Resar, J. R. (2011). Platelet Function in Patients with Diabetes Mellitus: From a Theoretical to a Practical Perspective. International Journal of Endocrinology, http://dx.doi.org/10.1155/2011/742719

[16] Uko, E. K., Erhabor, O., Isaac, I. Z., Abdulrahaman, Y., Adias, T. C., Sani, Y., Shehu, R. S., Liman, H. M., Dalltu, M. K. and Mainasara, A. S. (2013) Some Haematological Parameters in Patients with Type-1 Diabetes in Sokoto, North Western Nigeria. J Blood Lymph, 3: 110. doi: 10.4172/2165-7831.1000110

[17] Etim, N. N., Williams, M. E., Akpabio, U. and Offiong, E. E. A. (2014). Haematological Parameters and Factors Affecting Their Values. Agricultural Science, 2(1): 37-47.

[18] Zhao, Y., Zhang, J., Zhang, J. and Wu, J. (2011). Diabetes Mellitus Is Associated with Shortened Activated Partial Thromboplastin Time and Increased Fibrinogen Values. Plos One, 6(1):1-4.

[19] Eledo, B. O., Dioka, C. E., Amilo, G. I., Ifeanyichukwu, M. O. and Onuoha, E. C. (2015). Evaluation of Some Haematological Parameters Among Marijuana Smokers In Yenagoa, Nigeria. Journal of Biology, Agriculture and Healthcare, 5(12): 103-111.

[20] Ben-Eledo, V. N., Kigigha, L. T., Izah, S. C. and Eledo, B. O. (2017). Water quality assessment of Epie creek in Yenagoa metropolis, Bayelsa state, Nigeria. Archives of Current Research International, 8(2): 1-24.

[21] Ben-Eledo, V. N., Kigigha, L. T., Izah, S. C. and Eledo, B. O. (2017). Bacteriological Quality Assessment of Epie Creek, Niger Delta Region of Nigeria. International Journal of Ecotoxicology and Ecobiology, (3): 102-108.

[22] Ogamba, E. N., Seiyaboh, E. I., Izah, S. C., Ogbugo, I. and Demedongha, F. K. (2015). Water quality, phytochemistry and proximate constituents of Eichhorniacrassipes from Kolo creek, Niger Delta, Nigeria. International Journal of Applied Research and Technology, 4(9):77-84.

[23] Ogamba, E. N., Izah, S. C. and Oribu, T. (2015). Water quality and proximate analysis of Eichhorniacrassipes from River Nun, Amassoma Axis, Nigeria. Research Journal of Phytomedicine, 1(1): 43-48.

[24] Ogamba, E. N., Izah, S. C. and Toikumo, B. P. (2015). Water quality and levels of lead and mercury in Eichhorniacrassipes from a tidal creek receiving abattoir effluent, in the Niger Delta, Nigeria. Continental Journal of Environmental Science, 9(1): 13-25.

[25] Ogamba, E. N., Ebere, N. and Izah, S. C. (2017). Heavy Metal Concentration in Water, Sediment and Tissues of Eichhorniacrassipes from Kolo Creek, Niger Delta. Greener J. Environ. Manage. Public Safety. 6 (1): 001-005.

[26] Ogamba, E. N., Ebere, N. and Izah, S. C. (2017). Levels of lead and cadmium in the bone and muscle tissues of Oreochromisniloticus and Clarias camerunensis. EC Nutr. 7(3): $117-123$. 
[27] Seiyaboh, E. I., Izah, S. C. and Oweibi, S. (2017). Physicochemical Characteristics of Sediment from Sagbama Creek, Nigeria. Biotechnological Research, 3(1): 25-28.

[28] Seiyaboh, E. I., Izah, S. C. and Bokolo, J. E. (2017). Bacteriological quality of water from river nun at AmassomaAxises, Niger Delta, Nigeria. ASIO Journal of Microbiology, Food Science \& Biotechnological Innovations, 3(1), 22-26.

[29] Seiyaboh, E. I., Izah, S. C. and Oweibi, S. (2017). Assessment of Water quality from Sagbama Creek, Niger Delta, Nigeria. Biotechnological Research, 3(1):20-24.

[30] Seiyaboh, E. I., Inyang, I. R. and Izah, S. C. (2016). Seasonal Variation of Physico-Chemical Quality of Sediment from Ikoli Creek, Niger Delta. Intern. J. Innov. Environ. Stud. Res. 4(4): 29-34.

[31] Seiyaboh, E. I., Inyang, I. R. and Izah, S. C. (2016). Spatial Variation in Physico-chemical Characteristics of Sediment from Epie Creek, Bayelsa State, Nigeria. Greener J. Environ. Manage. Public Safety, 5(5): 100-105.

[32] Seiyaboh, E. I. and Izah, S. C. (2017). Bacteriological assessment of a tidal creek receiving slaughterhouse wastes in Bayelsa state, Nigeria. Journal of Advances in Biology and Biotechnology, 14(1): 1-7.

[33] Seiyaboh, E. I. and Izah, S. C. (2017). Review of Impact of Anthropogenic Activities in Surface Water Resources in the Niger Delta region of Nigeria: A case of Bayelsa state. International Journal of Ecotoxicology and Ecobiology, 2(2): 61-73.
[34] Alao, O. O., Damulak, D., Joseph, D. and Puepet, F. H. (2010). Haemostatic Profile of Patients with Type 2 Diabetes Mellitus in Northern Nigeria. The Internet Journal of Endocrinology, 6(1):1-5.

[35] Abdulrahaman, Y. and Dallatu, M. K. (2010). Evaluation of Prothrombin Time and Activated Partial Thromboplastin in Patients with Diabetes Mellitus. Nigerian Journal of Basic and Applied Science, 20(1): 60-63.

[36] Karim, F., Akter, Q. S., Jahan, S., Khanom, A., Haque, S., Yeasmin, T., Siddika, T. and Sinha, S. (2015). CoagulationImpairmentin Type 2 DiabetesMellitus. $J$ Bangladesh Soc Physiol., 10(1): 26-29.

[37] Wang, H., Niu, Y. Y., Si, W., Li. Y. J. and Yan, Y. (2012). Reference data of clinical chemistry, haematology and blood coagulation parameters in juvenile cynomolgus monkeys (Macacafascicularis). VeterinarniMedicina, 57(5): 233-238.

[38] Sapkota, B., Shrestha, SK. and Poudel, S. (2013). Association of activated partial thromboplastin time and fibrinogen level in patients with type II diabetes mellitus. BMC Research Notes, 6:485.

[39] Colwell, J. A. and Nesto, R. W. (2003). The Platelet in Diabetes. Focus on prevention of ischemic events. Diabetes Care 26(7): 2181-2188.

[40] Asif, M., Karim, S., Umar, Z., Malik, A., Ismail, T., Chaudhary, A., Alqahtani, M. H. and Rasool, M. (2013). Effect of cigarette smoking based on hematologicalparameters: comparison between male smokers and non- smokers. Turkish Journal of Biochemistry, 38 (1): $75-80$. 